E.T. PREL

Fish physiology

\title{
EFFECT OF VOLTAGE GRADIENT IN AN ELECTRICAL FIELD ON THRESHOLD INDICES OF FISH RESP ONSE
}

\section{WPŁYW GRADIENTU NATĘŻENIA POLA ELEKTRYCZNEGO NA PROGOWE WIELKOŚCI REAKCJI RYBY}

\author{
Technical Institute of Fisheries, Astrakhan
}

\begin{abstract}
The work presents experimental methods and effect of an electric field of alternating current potential changes on threshold values of some fish species from the Volga delta response.

It was noted, the fish response towards an electric field of alternating current changes to depend on speed of the field changes. An advice how to use it for fishing has been pointed out. Relation between the speed of electric field ponential changes and fish response to it has been determined.
\end{abstract}

\section{INTRODUCTION}

Studies of general problems concerning the effect of a.c. and d.c. fields on fishes, and the detection of its mechanism go back to the seventies of the last century. These problems have been drawing close attention, especially after some directed and stunning effects of an electric current on fishes were detected. The analysis of fish behaviour due to the electric current variables applied, environmental conditions and the state of the fish under study was also of great interest. The efforts of scientists were mostly directed to the detection of the threshold values of electric field voltage for some fish responses, from a minimal one (starting) to the state of an electric shock (narcosis).

Many research workes dealing with the electrical fields of alternating and direct current observed a different influence of the field on the fish due to the period of a current intensity increase.

In their survey Nusenbaum and Faleeva (Нусенбаум и фапеева, 1961) reported that Scheminsky and Nicolai (Scheminsky, 1924, 1936; Nicolai, 1930) in their 
experiments applied, with a gradual increase of field voltage, the current of a higher density for obtaining certain fish response. In the a.c. fields( Лосев, 1971; Стернин и лр., 1972) the rate of the increase of current intensity exerted some influence on fish threshold sensivity. In details this problem has not been studied in our country and abroad.

Numerous experiments on various easily excited organs and tissues demonstrated that the sensivity threshold depends upon a stimulus gradient (Макаров, 1952; Кроль, 1969 и лр. ). In a more general aspect this relationship was suggested by Rosental and Del Poso (Кропь, 1969):

$$
\mathrm{F}-\mathrm{F}_{\text {thr. } 0}=\mathrm{m} \cdot \mathrm{t}^{\mathrm{n}}
$$

where $F_{\text {thr } 0}$ - sensivity threshold for an instantly increasing stimulus;

$\mathrm{F}^{\text {thr.0 }}$ - threshold for the stimulus gradually increasing during some period of time $(t)$;

m - proportionality factor;

$\mathrm{n} \quad$ - index of an accomodation process;

During electric fishing quite different fish responses on the effects of electrical fields were observed. The two variants of field voltage increase were especially mentioned ( Нусенбаум, Фалеева, 1961). If current was switched on with the electrode being quite near the fish, the latter was acted upon by a quickly increasing voltage. If the electrode was being gradually brought to the fish, this caused smooth and gradual increase of current intensity.

According to many authors, the boundary conditions for regulated motion of the fish in an electrical field are very close to those causing deep depression or strunning of the fish. That is why one should be aware, in any concrete situation, of an admissible rate of bringing electrodes close to the fish (the rate of voltage increase in an electrical field).

This condition acquires special importance for laboratory experiments on the effect of electrical fields on fish behaviour. In such a case it is necessary to be aware of the limits in which the effect of voltage gradient in electrical fields should be taken into consideration or not, in other words, whether this factor influences on the threshold indices of fish response or not.

In this paper the results of investigations on the effects of a voltage gradient in. a.c. and d.c. electrical fields on the threshold response of some commercial fishes in the Delta of Volga are presented. Fingerlings of some commercial and pond fishes were also studied in this respect. 


\section{METHODS OF EXPERIMENTS}

A series of experiments were carried out in a glass aquarium of $60 \times 40 \times 20 \mathrm{~cm}$ with the electrodes of stainless steel (Fig. 1). For the best orientation between the electrodes the fish were placed between net partitions not to allow them to deviate from a set direction in an electric field.

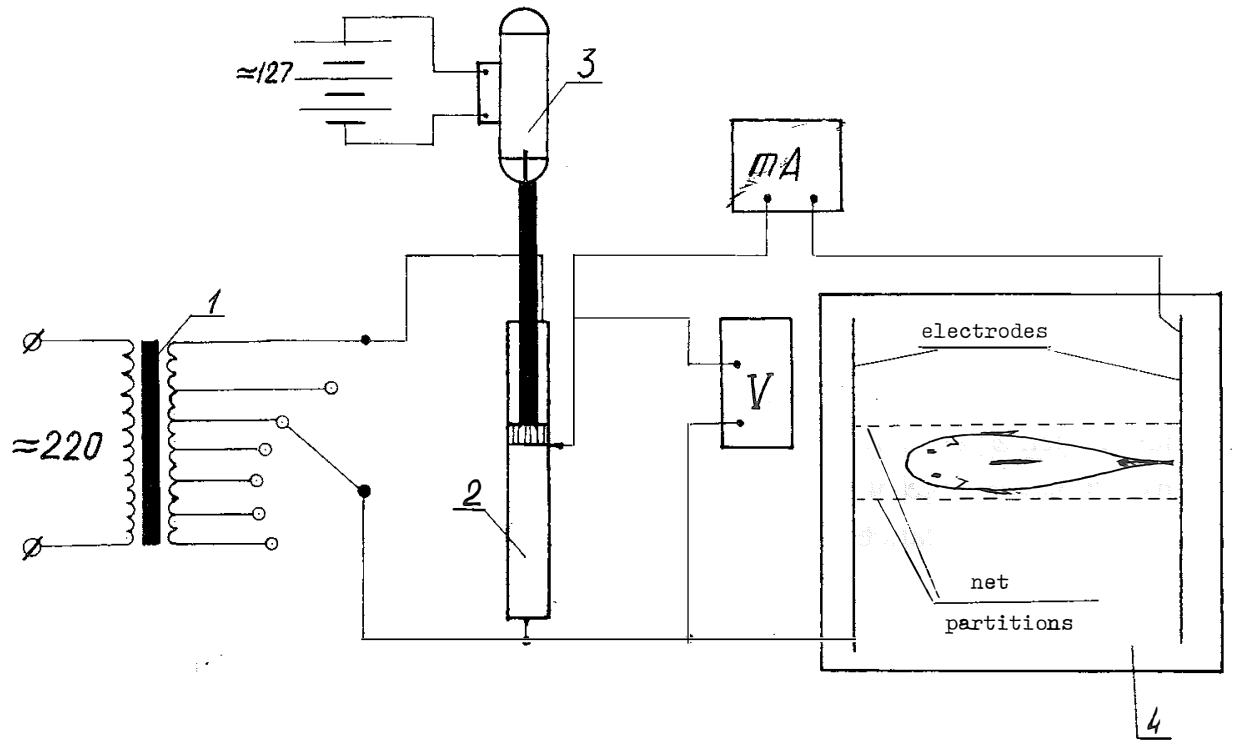

Fig. 1. Diagram of the experimental installation

The rate of intensity alteration in the field (voltage gradient) was secured by a smooth and gradual voltage transformation on the electrodes in the aquarium 4 by rheostat 2 with its slide being moved by motor 3. By changing the motor speed (number of revolutions) and the voltage from transformer I to the rheostat the rate of voltage increase on the electrodes was regulated in the range of $0-1.5$ $\mathrm{V} / \mathrm{sec}$. This was in full agreement with the tasks of our experiment. When the motor was started, and the slide of the rheostat was moving at a constant speed and passing zero mark (with voltage on the electrodes equal to 0 ), the button of a stop-watch was pushed on and then off at the moment of the fish response setting in. The voltage on the electrodes was calculated by indications on the stop-watch and by the rate of voltage increase on the electrodes. Then the voltage of the electrical field was calculated:

$$
U=t \cdot V_{u}, \quad V_{E_{0}}=\frac{V_{u}}{L}, \quad E_{0}=\frac{t \cdot V_{u}}{L}
$$




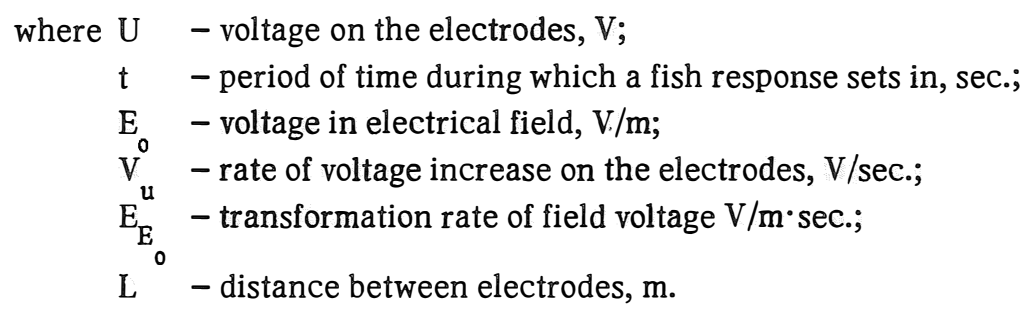

All the experiments were carried out in series in the laboratories of the Technical Institute of Fisheries, and in the fishing grounds of Volga. The specimen of definite species and equal size were chosen for each series. Constant temperature and electrical conductivity of water were being maintained.

Number of experiments in each series and statistical treatment of the results were in accord with common methods (Шеитяков, 1970).

The setting on of a fish response was detected visually. In table 1 only such reactions as starting and electric shock are presented as being more evident and less dependent upon a personal judgement.

Conventional voltage of a fish body $\left(\mathrm{U}_{1}\right)$ was calculated by the voltage on the electrodes $(\mathrm{U})$, the distance between the electrodes $(\mathrm{L})$, and fish body length $\left(1_{\mathrm{p}}\right)$ :

$$
\mathrm{U}=\frac{\mathrm{U}}{\mathrm{L}} \cdot \mathrm{p}_{\mathrm{p}}, \quad\left(\mathrm{U}_{1}\right)_{\mathrm{n}}=\mathfrak{t} \cdot \mathrm{V}_{\mathrm{E}}{ }_{0}^{\circ} \mathrm{p}_{\mathrm{p}}
$$

where $U_{1}$ - conventional voltage of fish body, $V$;

$1_{p}$ - fish body length, Sm.

\section{RESULTS}

Table 1 data were used for drawing the graphs of relationship between the thershold values of fish body conventional voltage $\left(\mathrm{U}_{1}\right)_{n}$ and the rate of voltage transformation on the electrodes $\left(V_{1}\right)_{n}$ and the rate of voltage transformation on the electrodes $\left(\mathrm{V}_{\mathrm{u}}\right)$, Fig. 2.

For all series of experiments the character of the graphs was identical, and independent on the place of an experiment, temperature and electrical conductivity of water, fish length and species. The graphs for starting and electrical shock responses are represented by a linear dependence. For the interval $V_{u}=(0.2 \div 1.5) \mathrm{V} /$ sec the threshold values of variable $U_{1}$ (starting response) decrease with an increase of rate, and for an electric shock response they increase.

In Fig. $3\left(U_{1}\right)_{n}=G(t)$ for starting response confirm, in all the cases, entire biological dependence deduced for the sensitivity threshold, and for an electric shock 
Relationship between threshold values $\left(U_{1}\right)$ of fish response and stimulus alternation rate $\gamma_{8}=35.5 \mathrm{mSim} / \mathrm{m} \quad \mathrm{t}^{\circ}=12+13^{\circ} \mathrm{C}$

\begin{tabular}{|c|c|c|c|c|c|c|c|c|c|c|c|c|c|}
\hline \multirow{2}{*}{\multicolumn{2}{|c|}{$\begin{array}{l}\text { Voltage gradient } v_{u} \\
\text { Species, length, response }\end{array}$}} & \multicolumn{3}{|c|}{$0.2 \mathrm{~V} / \mathrm{sec}$} & \multicolumn{3}{|c|}{$0.3 \mathrm{~V} / \mathrm{sec}$} & \multicolumn{3}{|c|}{$0.4 \mathrm{~V} / \mathrm{sec}$} & \multicolumn{3}{|c|}{$0.5 \mathrm{~V} / \mathrm{sec}$} \\
\hline & & $\bar{n}$ & $\mathrm{t}$ & $\mathrm{U}_{1}$ & $\mathrm{n}$ & $\mathrm{t}$ & $\mathrm{U}_{1}$ & $\mathrm{n}$ & $t$ & $\mathrm{U}_{1}$ & $\mathrm{n}$ & $t$ & $\mathrm{U}_{1}$ \\
\hline & & 2 & 3 & 4 & 5 & 6 & 7 & 8 & 9 & 10 & 11 & 12 & 13 \\
\hline Bream & Starting & 28 & 3.01 & 0.82 & 25 & 4.62 & 0.92 & 25 & 3.42 & 0.92 & 26 & 2.48 & 0.8 \\
\hline $28-31 \mathrm{~cm}$ & Electric shock & 25 & 24.5 & 3.97 & 25 & 10.2 & 3.01 & 25 & 12.2 & 2.99 & 26 & 10.1 & 3.09 \\
\hline Casp.roach & Starting & 28 & 5.63 & 0.67 & 27 & 3.16 & 0.55 & 28 & 2.55 & 0.52 & 26 & 2.2 & 0.56 \\
\hline $26-28 \mathrm{~cm}$ & Electric shock & 25 & 31.7 & 4.88 & 25 & 24.8 & 5.42 & 25 & 18.8 & 5.79 & 25 & 15.2 & 5.81 \\
\hline Sazan & Starting & 26 & 14.6 & 2.35 & 25 & 11.32 & 2.53 & 24 & 7.07 & 2.06 & 27 & 5.49 & 2.07 \\
\hline $43-47 \mathrm{~cm}$ & Electric shock & 28 & 23.04 & 4.43 & 29 & 16.1 & 4.52 & 29 & 11.9 & 4.6 & 28 & 9.38 & 4.93 \\
\hline
\end{tabular}

\begin{tabular}{|c|c|c|c|c|c|c|c|c|c|c|}
\hline \multicolumn{2}{|r|}{$\mathrm{I}$} & 14 & 15 & 16 & 17 & 18 & 19 & 20 & 21 & 22 \\
\hline \multicolumn{2}{|r|}{$\nabla_{u}$} & \multicolumn{3}{|c|}{$0.75 \mathrm{~V} / \mathrm{sec}$} & \multicolumn{3}{|c|}{$1.0 \mathrm{~V} / \mathrm{sec}$} & \multicolumn{3}{|c|}{$1.5 \mathrm{~V} / \mathrm{sec}$} \\
\hline Bream & Starting & 26 & 1.76 & 0.81 & 29 & 1.01 & 0.72 & 29 & 0.58 & 0.63 \\
\hline $28-31 \mathrm{~cm}$ & Electric shock & 29 & 6.78 & 3.15 & 27 & 4.99 & 3.13 & 27 & 3.5 & 3.65 \\
\hline Casp. roach & Starting & 25 & 1.34 & 0.51 & 25 & 0.92 & 0.46 & 30 & 0.58 & 0.43 \\
\hline $26-28 \mathrm{~cm}$ & Electric shock & 26 & 12.4 & 5.98 & 26 & 8.14 & 6.1 & 26 & 6.12 & 7.2 \\
\hline Sazan & Starting & 27 & 3.96 & 2.04 & 77 & 2.39 & 1.94 & 28 & 1.57 & 1.69 \\
\hline $43-47 \mathrm{~cm}$ & Electric shock & 27 & 5.46 & 5.26 & 25 & 4.46 & 5.64 & 29 & 3.44 & 5.71 \\
\hline
\end{tabular}

Note: $n$ - quantity of specimen; $t$ - time (sec.); $U_{1}$ - conventional voltage in fish. 


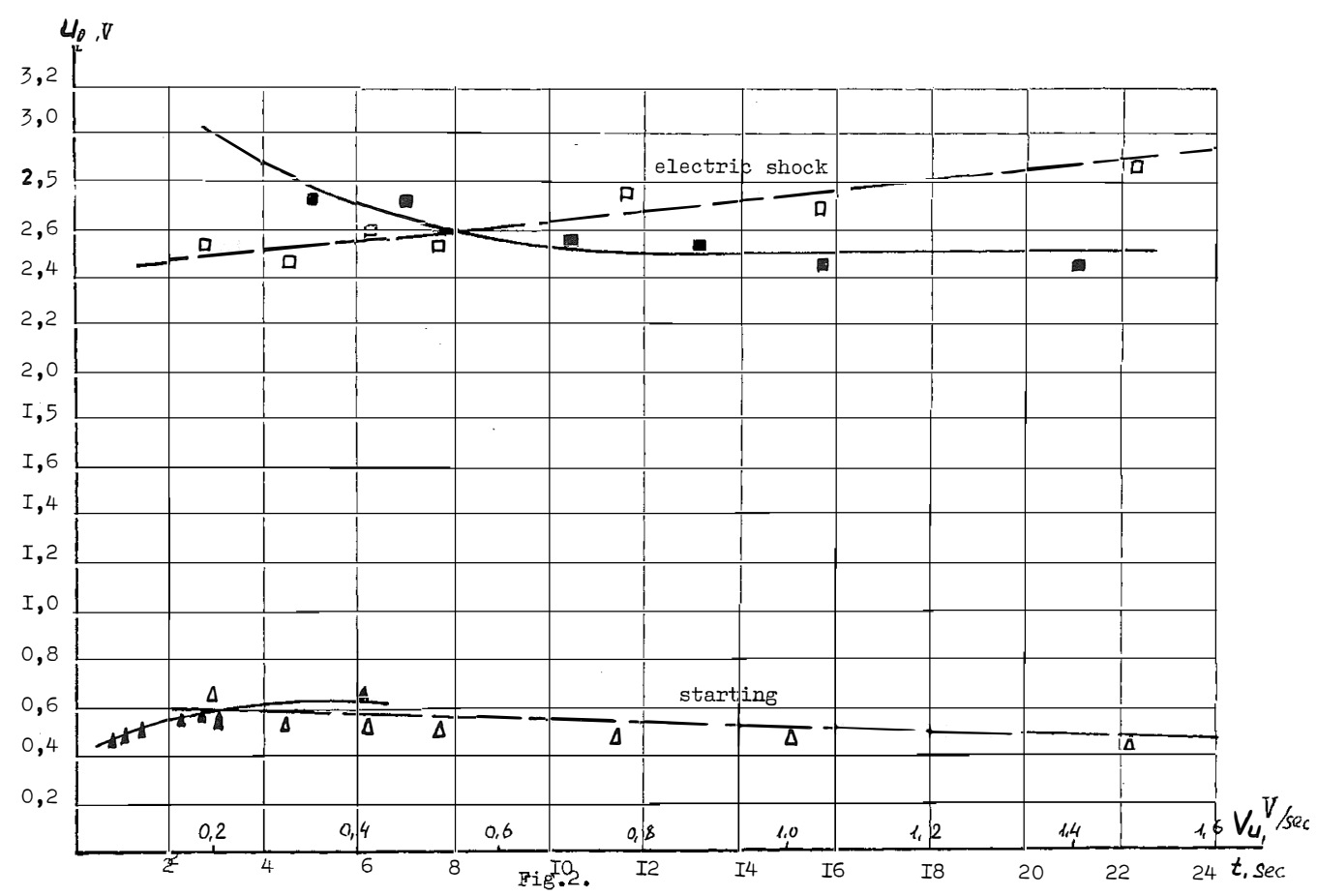

Relationship between threshold values of conventional voltage in fish body and stimulus alternation rate

$\left(U_{1 n}=f(t)\right.$

they are represented by hyperbolic curves. Analogous relations are obtained for the reactions of the fish under the effects of pulsed electrical fields (Ланюлите,1960).

\section{DISCUSSION}

The character of the relations obtained are likely to be explained by the characteristics of fish as a biological object. Thus for a starting response (as well as for sensivity threshold to tissues and organs) an increase of threshold values of $U_{1}$ at low values of the stimulus gradient and its prolonged action is expained by the ability of a living organism to adapt to weak stimuli (irritants).

A decrease of $\left(U_{1}\right)_{n}$ for the shock response at lower stimulus gradients is likely to be explained by some properties of living organisms, by exhibiting a cumulative 
effect, for example, when the setting in of a response depends upon the total volume of stimulus. In our studies the phenomenon of accumulation was observed at $\mathrm{V} \leqslant 0.68 \mathrm{~V} / \mathrm{sec}$. with the period of effect over 6 seconds.

Graphic data in Fig. 2 show that the phenomenon of accomodation and and cumulative effect exert a-profound influence on the threshold values of fish response. For example, variable $\left(\mathrm{U}_{1}\right)_{\mathrm{n}}$ for electric shock response as well as for starting one decreases $(35 \div 55 \%)$ for all fish species.

This investigation and the results obtained made it possible to draw some practical conslusion. All the mobile electric fishing gear with the electric fields aimed to alter the motion activity of the fish should be displaced at a low speed with the voltage on the electrodes being decreased. This must be taken into account to minimize fish damage in electrical fields, especially of the fish left in water (not caught). This condition must be also observed for the reason that some fish from a catch may be used as a source of replenishment for breeder's stocks.

\section{REFERENCES}

Данплите Г.П., 1960: Научно-технический отчет по теме „Реакцйия морских рыб на электрошок”. Фонд К.О. Гидрорыбфлота.

Крољ Т.М., 1969: Математическое толкование зависимости светового и потока от градиента стимула. В кн. „Применение математических методов в биологии1. Съ.4, Изг-во Ленинтрадского университета.

Лосев Ю.М., 1971: Влияние скорости нарастания переменного электротока на пороговую чувствительность рыб. „Рыбное хозяйство”.

Макаров П.С., 1952: Нейродинальикая зрательной системы. М.Нагкя.

Нусенаум Л.М., Т.И. Фалеева, 1961: Исследование поведения рыбы в электрическом ноле. Изв. ГосНИОРХ, т.52, вып.1, 91 с.

IIIентяков В.А., 1970: Методика статистической обработки параметров, опрелделяющих реакции рыб в электрических полях. „Промышленное рыболовство”, сер.2, вып.1, ЦНИИТЭИРХ.

Nicolai L., 1930: Über elektrotaxis und elektonarkose von Fischen. „Pflügers Arch. fd. ges. Physiol. Bd. 224.H.1.

Scheminsky F., 1924: Versuche über elektrotaxis und elektronarkose "Pflügers Arch. fd. ges. Physiol.", BD.202.

Scheminsky F., 1936: Zur Physiologie des Galvanonarkose bei Wssertieren. "Pflügers Arch. fd. ges. Physiol”. Bd. 237, H3. 


\section{E.T. PREL}

\section{WPEYW GRADIENTU NATĘŻENIA POLA ELEKTRYCZNEGO NA PROGOWE WIELKOŚCI REAKCJI RYBY \\ STRESZCZENIE}

Przedstawiono metodykę prac eksperymentalnych i wyniki badań wpływu zmian potencjału pola elektrycznego prądu zmiennego na progowe wielkości reakcji na to pole kilku gatunków ryb z delty Wołgi.

Stwierdzono, że reakcja ryby na parametry pola elektrycznego prądu zmiennego zależy od szybkości zmian tego pola i wskazano $w$ jaki sposób powinno to być wykorzystane w procesie połowu. Określono charakter zależności pomiędzy prędkością zmian potencjału pola elektrycznego i reakcją ryb na to pole.

Author's address:

E.T. Prel

Technical Institute of Fischeries

Astrakhan, USSR 